\title{
Status of benzimidazole resistance in intestinal nematode populations of livestock in Brazil: a systematic review
}

\author{
Lauren Hubert Jaeger ${ }^{1 *}$ and Filipe Anibal Carvalho-Costa ${ }^{1,2}$
}

\begin{abstract}
Background: Benzimidazoles (BZ) are a class of drugs widely used in veterinary and human medicine, creating a great selection pressure and the emergence of BZ resistance. We conducted a systematic review to assess the status of resistance and/or effectiveness reduction of BZ drugs in animal nematodes in Brazil, and make information accessible to the scientific community, as many studies are published in Portuguese. PubMed, SciELO Brasil, LILACS/Bireme, GNTD database, and Google Scholar were searched with no language restrictions.

Results: A total of 40 studies met our eligibility criteria (from the year 1989 forward). Sheep was the host most frequently analysed, and albendazole was the most frequently drug studied. The majority of studies (75.7\%) showed that BZ drugs are insufficiently active (FECRT <80\%) against nematode parasites of livestock. The mean FECRT for fenbendazole, thiabendazole, albendazole, mebendazole, oxfendazole, and ricobendazole were $71.8 \%, 71.8 \%, 58.6 \%$, $53.9 \%, 46.9 \%$, and $41.5 \%$, respectively. It was observed through linear regression that FECRT is significantly reduced over time between 2007 and $2014(R=-0.653 p=0.021)$ for the treatment of cattle with $B Z$, suggesting progressive loss of effectiveness and increased resistance for these hosts.
\end{abstract}

Conclusions: The scenario of BZ resistance in nematode populations in Brazil is not favourable. Given the high cost of drug discovery and development, it is urgent to implement control measures and to monitor the effectiveness/ resistance to nematodes in livestock in Brazil.

Keywords: Benzimidazole, Anthelmintic resistance, Nematodes, Livestock, Brazil

\section{Background}

Livestock production is undermined by intestinal parasitic diseases [1]. The high prevalence of parasitic infections and the difficulty of carrying out effective control of these parasites in livestock can cause huge economic losses in production [2]. In addition to the damage caused by high mortality rates, intestinal parasites impact growth performance, reduce milk production and lead to low fertility [3]. The most important genera affecting livestock in Brazil include Haemonchus, Trichostrongylus, Oesophagostomum, and Cooperia [3]. The cost of veterinary products is approximately 15 billion US dollars annually worldwide, and $27 \%$ of this cost is represented by parasiticides. In

\footnotetext{
* Correspondence: laurenhj@hotmail.com

${ }^{1}$ Laboratório de Epidemiologia e Sistemática Molecular, Instituto Oswaldo Cruz, Fundação Oswaldo Cruz, Pavilhão Leônidas Deane, sala 308, Avenida Brasil 4365, Manguinhos, Rio de Janeiro, RJ 21040-900, Brazil

Full list of author information is available at the end of the article
}

Brazil, parasiticide purchases constitute $42 \%$ of the total volume of veterinary sales, representing 700 million US dollars annually [3]. Brazilian cattle herds reached 211,764 million animals in 2013, comprising the world's largest commercial herd. Brazilian sheep and goat herds comprised 17,291 million and eight million animals, respectively [4].

Benzimidazoles (BZ) are a class of drugs with activities against fungi, protozoa, and helminths $[5,6]$ and are widely used in veterinary and human medicine. The introduction of thiabendazole (THI) in the 1960s - the prototype of the first generation of benzimidazoles provided a breakthrough in the treatment of diseases, allowing for the development of several other members of this class [5]. The primary mode of action of these drugs involves their interaction with the cytoskeletal protein $\beta$-tubulin, which together with $\alpha$-tubulin constitutes the main component of microtubules [7]. 
The BZ drugs have many benefits, including the following: i) selectivity and relatively low mammalian toxicity; ii) broad spectrum of activity; iii) high efficacy; iv) ease of administration; and v) low cost [5, 7-9]. For this reason, BZ drugs are widely used in livestock and are currently being employed in human MDA strategies. The success of anthelmintic treatment in the management and control of parasitic infections in livestock in the years following the development of $\mathrm{BZ}$ led to frequent and indiscriminate use of these drugs, thereby creating a great selection pressure in multiple species of nematodes [10]. This has the potential to select for parasite genotypes that are resistant to anthelmintics [11]. Drug resistance in any organism is defined by a change in the drug's pharmacokinetics and pharmacodynamics (absorption, distribution, metabolism, excretion, and site of action) [5] that allows some individuals in a population to tolerate doses of a given compound that would not normally be tolerated.

In this systematic review, we assess the status of resistance and/or effectiveness reduction of benzimidazole drugs in livestock nematodes in Brazil to review the history of BZ resistance in the country, generate data to enable monitoring and verification of the spread of $\mathrm{BZ}$ resistance, and make information accessible to the scientific community, as many studies are published in Portuguese.

\section{Methods}

\section{Data sources and inclusion/exclusion criteria}

Surveys assessing BZ resistance pertaining to animal intestinal nematodes in Brazil were extracted from five electronic databases: PubMed/NCBI (US National Library of Medicine National Institutes of Health/National Center for Biotechnology Information Search database), SciELO Brasil (Scientific Electronic Library Online), LILACS-Bireme (Biblioteca Virtual em Saúde - BIREME/ PAHO/WHO), GNTD database (Global Neglected Tropical Diseases database), and Google Scholar. The search was performed on November 21st, 22nd, and 28th, 2015, using the terms: "resistance", AND "benzimidazole", OR "albendazole", OR "mebendazole", AND "Brazil". No language restrictions were made. Duplicate papers were removed. The PRISMA guideline/checklist was used to construct the systematic review [12].

Studies were eligible for inclusion if they met the following criteria: i) evaluated the BZ resistance/efficacy in nematode parasites in livestock hosts; ii) studied natural infections; iii) showed BZ resistance/efficacy of at least one $\mathrm{BZ}$ anthelmintic; iv) used at least one technique to detect $\mathrm{BZ}$ resistance/effectiveness; and v) were published in scientific journals with an International Standard Serial Number (ISSN). Congress abstracts, theses, and dissertations were not included. The exclusion criteria were as follows: i) articles that explored the BZ resistance only associated with other drug classes (e.g., $\mathrm{BZ}+$ macrocyclic lactones and other associations); ii) studies evaluating BZ resistance on fungi or other microorganisms; and iii) works demonstrating only experimental infections or in vitro tests.

"Grey literature" was accessed to enrich the text but was not included in the systematic review.

\section{Data extraction, analysis, and quality assessment}

Once selected, the following data were extracted from each paper and entered into a Microsoft Office Excel database: author names, journal, publication year, language, state and city in which the study was performed, host types, number of hosts, BZ drugs, parasitological techniques, counts of eggs per gram (epg) of faeces, parasites genus/species found, control group, if animal was dewormed and for how long, BZ resistance-related single nucleotide polymorphisms (SNPs) found, efficacy, cure rate, and reinfection rate. The studies were categorized into five quality levels ( 1 to 5 ; data not shown) based on the detail of the herds, number of animals evaluated, drugs evaluated, number and quality of the parasitological techniques used, and FECRT calculation.

\section{Faecal egg count reduction test analysis}

An assessment of treatment efficacy was performed by analysing the Faecal Egg Count Reduction Test (FECRT syn. Egg reduction rate/ERR) results. When the studies did not present FECRT results, the values were calculated based on the eggs per gram of faeces before and after treatment, according to [13]. For the interpretation of the FECRT results in livestock, the following criteria were used: FECRT $>98 \%$, highly effective; FECRT 90 98\%, effective; FECRT $80-89 \%$, moderately effective; and FECRT $<80 \%$, insufficiently active [14].

The SPSS ${ }^{\circ}$ Statistic Software v.20 (IBM Corp., Armonk, USA) was used to simple linear regression analysis, with a statistical significance of $5 \%(p=0.05)$. We employed the general software Diva-GIS v.7.5.0.0 for map construction (downloaded free from the website: http://www.diva-gis.org).

\section{Results}

The search resulted in the gathering of 9176 files (articles or other texts). After applying the inclusion and exclusion criteria, 40 scientific articles were selected (Table 1). Most of the studies were published in Portuguese (23/40, 57.5\%), and $17(42.5 \%)$ studies were published in English. This review includes articles conducted from the year 1989 forward.

Data from 13 Brazilian states were analysed in the studies (Fig. 1). The largest number of studies was performed in Northeast (14/40,32.6\%), followed by Southeast (32.5\%), South (30.0\%), and Centre West (2.5\%). The states most frequently analysed were the following: São 
Table 1 List of studies assessing benzimidazole resistance in livestock hosts in Brazil, from 1989 to 2015

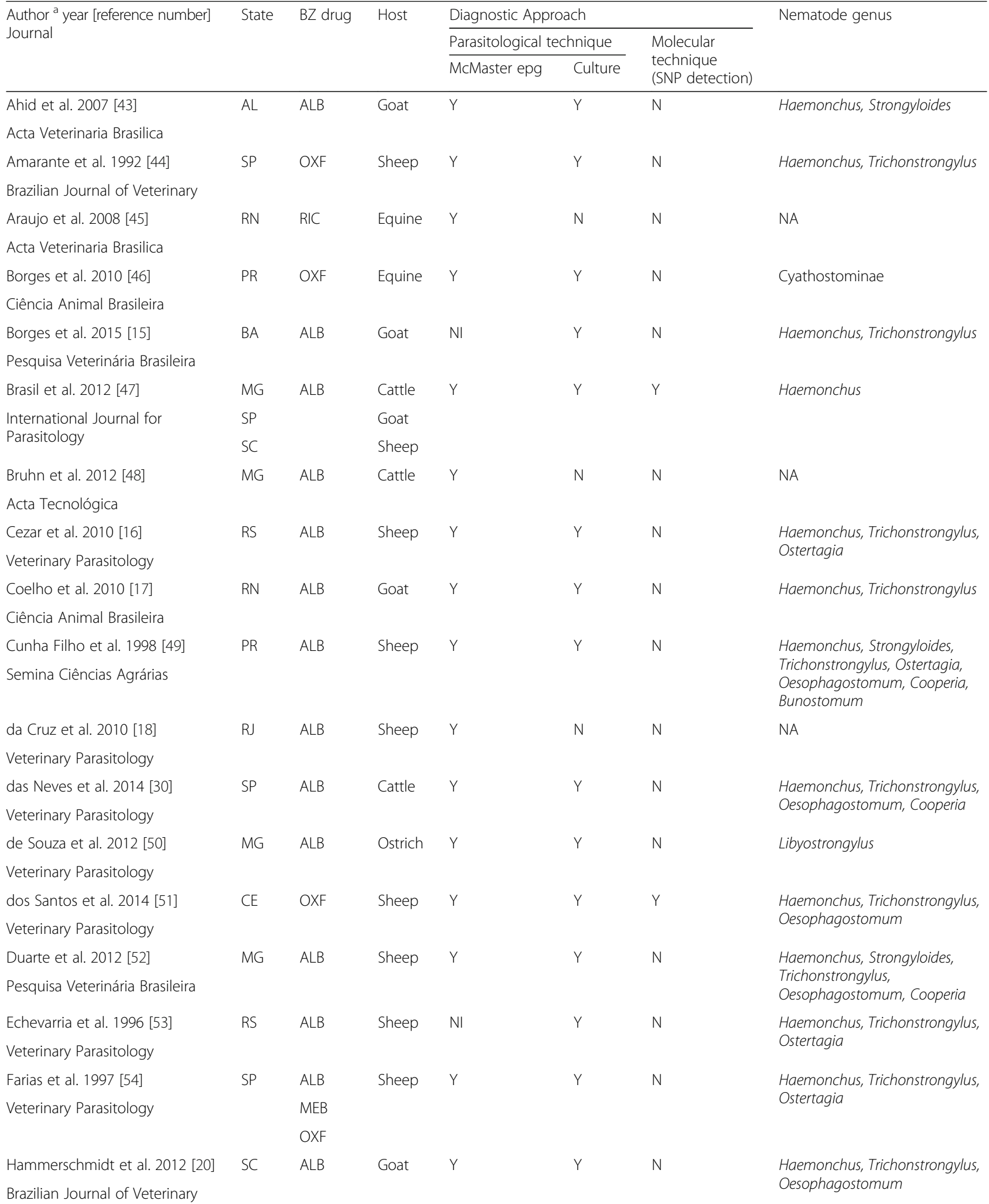


Table 1 List of studies assessing benzimidazole resistance in livestock hosts in Brazil, from 1989 to 2015 (Continued)

\begin{tabular}{|c|c|c|c|c|c|c|c|}
\hline \multirow{3}{*}{$\begin{array}{l}\text { Author }{ }^{a} \text { year [reference number] } \\
\text { Journal }\end{array}$} & \multirow[t]{3}{*}{ State } & \multirow[t]{3}{*}{ BZ drug } & \multirow[t]{3}{*}{ Host } & \multicolumn{3}{|c|}{ Diagnostic Approach } & \multirow[t]{3}{*}{ Nematode genus } \\
\hline & & & & \multicolumn{2}{|c|}{ Parasitological technique } & \multirow{2}{*}{$\begin{array}{l}\text { Molecular } \\
\text { technique } \\
\text { (SNP detection) }\end{array}$} & \\
\hline & & & & McMaster epg & Culture & & \\
\hline Klauck et al. 2014 [55] & \multirow[t]{2}{*}{ SC } & \multirow[t]{2}{*}{ ALB } & \multirow[t]{2}{*}{ Sheep } & \multirow[t]{2}{*}{ Y } & \multirow[t]{2}{*}{ Y } & \multirow[t]{2}{*}{$\mathrm{N}$} & \multirow{2}{*}{$\begin{array}{l}\text { Haemonchus, Trichostrongylus, } \\
\text { Cooperia, Teladorsagia }\end{array}$} \\
\hline $\begin{array}{l}\text { Annals of the Brazilian } \\
\text { Academy of Sciences }\end{array}$ & & & & & & & \\
\hline Lima et al. 2010 [56] & \multirow[t]{2}{*}{ PE } & \multirow[t]{2}{*}{ ALB } & Goat & \multirow[t]{2}{*}{ Y } & \multirow[t]{2}{*}{ Y } & \multirow[t]{2}{*}{$\mathrm{N}$} & \multirow{2}{*}{$\begin{array}{l}\text { Haemonchus, Trichonstrongylus, } \\
\text { Oesophagostomum }\end{array}$} \\
\hline Ciência Animal Brasileira & & & Sheep & & & & \\
\hline Lima et al. 2010 [57] & \multirow[t]{2}{*}{$P E$} & \multirow[t]{2}{*}{ ALB } & \multirow[t]{2}{*}{ Goat } & \multirow[t]{2}{*}{ Y } & Y & N & Haemonchus, Strongyloides, \\
\hline Pesquisa Veterinária Brasileira & & & & & & & $\begin{array}{l}\text { Irichonstrongylus, } \\
\text { Oesophagostomum }\end{array}$ \\
\hline Melo et al. 1998 [58] & CE & OXF & Sheep & Y & Y & $\mathrm{N}$ & Haemonchus, Trichonstrongylus, \\
\hline Ciência Animal & & & & & & & \\
\hline Melo et al. 2003 [59] & CE & OXF & Goat & Y & Y & N & Haemonchus, Trichonstrongylus, \\
\hline Ciência Rural & & & Sheep & & & & \\
\hline Niciura et al. 2012 [60] & SP & ALB & Sheep & $\mathrm{N}$ & $\mathrm{N}$ & Y & Haemonchus \\
\hline Veterinary Parasitology & & & & & & & \\
\hline Nunes et al. 2013 [61] & MG & ALB & Cattle & Y & N & Y & Haemonchus \\
\hline Revista Brasileira de & SP & & Goat & & & & \\
\hline Parasitologia Veterinaria & & & Sheep & & & & \\
\hline Pereira et al. 2008 [62] & $\mathrm{RN}$ & ALB & Goat & $\mathrm{NI}$ & Y & N & Haemonchus, Strongyloides, \\
\hline Acta Veterinaria Brasilica & & & Sheep & & & & $\begin{array}{l}\text { Trichonstrongylus, } \\
\text { Oesophagostomum }\end{array}$ \\
\hline Ramos et al. 2002 [63] & SC & ALB & Sheep & Y & Y & $\mathrm{N}$ & Haemonchus, Trichonstrongylus, \\
\hline Ciência Rural & & & & & & & Ostertagia \\
\hline Rodrigues et al. 2007 [64] & PB & ALB & Goat & Y & Y & $\mathrm{N}$ & Haemonchus \\
\hline Pesquisa Veterinaria Brasileira & & & & & & & \\
\hline Santos et al. 2014 [65] & RS & OXF & Cattle & Y & Y & $\mathrm{N}$ & Haemonchus, Trichonstrongylus, \\
\hline $\begin{array}{l}\text { Revista Portuguesa de } \\
\text { Ciências Veterinarias }\end{array}$ & & & & & & & \\
\hline Sczesny-Moraoes et al. 2010 [66] & MS & ALB & Sheep & Y & Y & $\mathrm{N}$ & Haemonchus, Strongyloides, \\
\hline Pesquisa Veterinária Brasileira & & & & & & & \\
\hline Soutelo et al. 2007 [67] & SP & ALB & Cattle & $\mathrm{Nl}$ & Y & $\mathrm{N}$ & Haemonchus, Trichonstrongylus, \\
\hline Veterinary Parasitology & & & & & & & Oesophagostomum, Cooperia \\
\hline Soutelo et al. 2010 [68] & SP & ALB & Cattle & Y & Y & $\mathrm{N}$ & Haemonchus, Oesophagostomum, \\
\hline $\begin{array}{l}\text { Revista Brasileira de } \\
\text { Parasitologia Veterinária }\end{array}$ & & & & & & & cooperia \\
\hline Souza et al. 2008 [69] & SC & ALB & Cattle & Y & Y & $\mathrm{N}$ & Cooperia \\
\hline Ciência Rural & & & & & & & \\
\hline Souza et al. 2013 [70] & PB & ALB & Goat & Y & $\mathrm{N}$ & $\mathrm{N}$ & NA \\
\hline $\begin{array}{l}\text { Agropecuária Científica } \\
\text { do Semiárido }\end{array}$ & & & & & & & \\
\hline Thomas-Soccol et al. 1996 [21] & PR & ALB & Sheep & Y & $\mathrm{N}$ & $\mathrm{N}$ & NA \\
\hline Veterinary Record & & & & & & & \\
\hline Thomas-Soccol et al. 2004 [22] & PR & OXF & Sheep & $\mathrm{NI}$ & Y & $\mathrm{N}$ & Haemonchus, Trichonstrongylus, \\
\hline $\begin{array}{l}\text { Brazilian Archives of } \\
\text { Biology and Technology }\end{array}$ & & & & & & & $\begin{array}{l}\text { Oesophagostomum, Ostertagia, } \\
\text { Cooperia }\end{array}$ \\
\hline
\end{tabular}


Table 1 List of studies assessing benzimidazole resistance in livestock hosts in Brazil, from 1989 to 2015 (Continued)

\begin{tabular}{|c|c|c|c|c|c|c|c|}
\hline \multirow{3}{*}{$\begin{array}{l}\text { Author }{ }^{a} \text { year [reference number] } \\
\text { Journal }\end{array}$} & \multirow[t]{3}{*}{ State } & \multirow[t]{3}{*}{ BZ drug } & \multirow[t]{3}{*}{ Host } & \multicolumn{3}{|c|}{ Diagnostic Approach } & \multirow[t]{3}{*}{ Nematode genus } \\
\hline & & & & \multicolumn{2}{|c|}{ Parasitological technique } & \multirow{2}{*}{$\begin{array}{l}\text { Molecular } \\
\text { technique } \\
\text { (SNP detection) }\end{array}$} & \\
\hline & & & & McMaster epg & Culture & & \\
\hline Veríssimo et al. 2012 [71] & \multirow[t]{2}{*}{ SP } & \multirow[t]{2}{*}{ ALB } & \multirow[t]{2}{*}{ Sheep } & \multirow[t]{2}{*}{$\mathrm{NI}$} & \multirow[t]{2}{*}{ Y } & \multirow[t]{2}{*}{$\mathrm{N}$} & \multirow{2}{*}{$\begin{array}{l}\text { Haemonchus, Strongyloides, } \\
\text { Trichonstrongylus, } \\
\text { Oesophagostomum, Cooperia }\end{array}$} \\
\hline Veterinary Parasitology & & & & & & & \\
\hline Vieira and Cavalcante 1999 [72] & \multirow[t]{2}{*}{ CE } & \multirow[t]{2}{*}{ OXF } & \multirow[t]{2}{*}{ Goat } & \multirow[t]{2}{*}{ Y } & \multirow[t]{2}{*}{ Y } & \multirow[t]{2}{*}{ N } & \multirow[t]{2}{*}{ Haemonchus, Oesophagostomum } \\
\hline Pesquisa Veterinária Brasileira & & & & & & & \\
\hline Vieira et al. 1989 [73] & \multirow[t]{4}{*}{ CE } & ALB & \multirow[t]{4}{*}{ Goat } & \multirow[t]{4}{*}{$\mathrm{Nl}$} & \multirow[t]{4}{*}{ Y } & \multirow[t]{4}{*}{$\mathrm{N}$} & \multirow{4}{*}{$\begin{array}{l}\text { Haemonchus, Trichonstrongylus, } \\
\text { Oesophagostomum }\end{array}$} \\
\hline \multirow{3}{*}{$\begin{array}{l}\text { Pesquisa Agropecuária } \\
\text { Brasileira }\end{array}$} & & FEN & & & & & \\
\hline & & OXF & & & & & \\
\hline & & $\mathrm{THI}$ & & & & & \\
\hline Vieira et al. 1989 [74] & \multirow[t]{4}{*}{ CE } & ALB & Goat & \multirow[t]{4}{*}{$\mathrm{Nl}$} & \multirow[t]{4}{*}{ Y } & \multirow[t]{4}{*}{$\mathrm{N}$} & \multirow[t]{4}{*}{ Haemonchus, Strongyloides } \\
\hline \multirow{3}{*}{$\begin{array}{l}\text { Boletim de Pesquisa } \\
\text { Embrapa }\end{array}$} & & FEN & \multirow[t]{3}{*}{ Sheep } & & & & \\
\hline & & OXF & & & & & \\
\hline & & THI & & & & & \\
\hline
\end{tabular}

Total $=40$

alisted alphabetically. $A L B$ albendazole, $F E N$ fenbendazole, MEB mebendazole, OXF oxfendazole, $R I C$ ricobendazole, $T H I$ thiabendazole. Epg eggs per gram of faeces, AL Alagoas, BA Bahia, CE Ceará, MG Minas Gerais, MS Mato Grosso do Sul, PB Paraíba, PE Pernambuco, PR Paraná, RJ Rio de Janeiro, $R N$ Rio Grande do Norte, $R S$ Rio Grande do Sul, SC Santa Catarina, SP São Paulo. Y Yes, N No, NI Not informed, NA Not applied

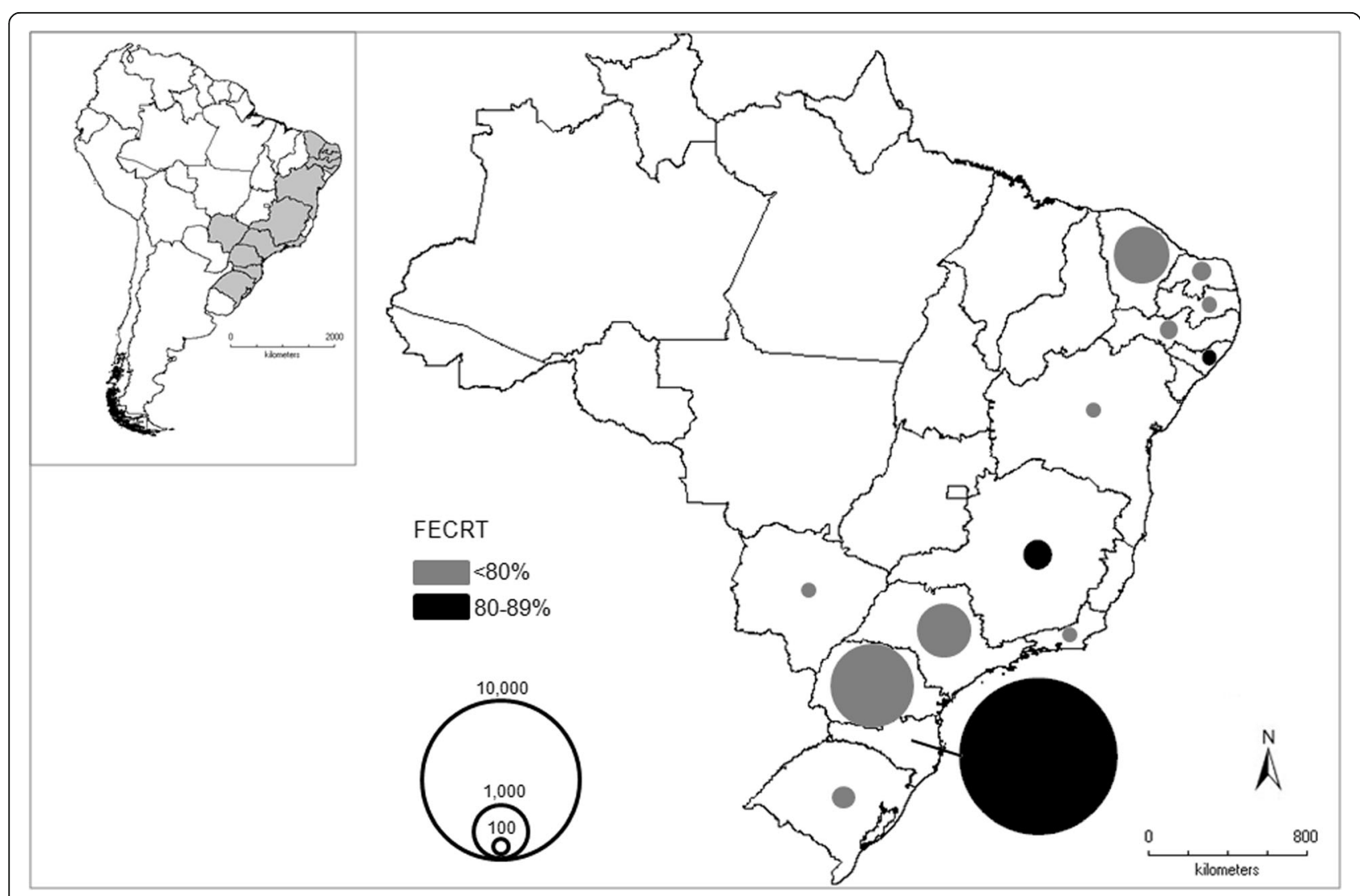

Fig. 1 Mean FECRT in livestock of the Brazilian states. Area of the circle is proportional to number of animals 
Paulo (9/40, 22.5\%), Ceará (15.0\%), and Minas Gerais and Santa Catarina (12.5\%) (Table 1).

In livestock, sheep were the host most frequently analysed $(23 / 40,57.5 \%)$ (Table 2$)$, followed by goats (37.5\%), cattle (17.5\%), and others (equines and ostrich, 7.5\% each). The BZ drugs tested in livestock were ALB (31/ 40, 72.1\%), oxfendazole (OXF) (27.5\%), fenbendazole (FEN) (4.7\%), THI (4.7\%), and MEB (2.3\%), and ricobendazole (RIC) (2.3\%).

The majority of studies (75.7\%) showed that BZ drugs are insufficiently active (FECRT $<80 \%$ ) against nematode parasites of livestock (Fig. 1). The mean FECRT for BZ drugs was $55.0 \%$ (Table 2); the mean FECRTs for FEN and THI was of $71.8 \%$, the mean for ALB was $58.6 \%$, the mean for MEB was $53.9 \%$, the mean for OXF was $46.9 \%$, and the mean for RIC was $41.5 \%$. Five studies showed FECRTs lower than $1 \%$. It is noteworthy that the most studied animal - sheep - showed the lowest mean FECRT for BZ drugs (mean FECRT $=47.0 \%$ ) (Table 2). Only one study (2.5\%) demonstrated that ALB is highly effective (FECRT > 98\%) in ostrich against the nematode genus Libyostrongylus.

Among the techniques used to perform the eggs counts, the Gordon and Whitlock technique associated with the McMaster chamber was the most frequently used (75.0\% of studies). The egg hatch test, as well as

Table 2 BZ effectiveness parameters in livestock nematodes in Brazil

\begin{tabular}{|c|c|c|c|c|c|}
\hline \multirow[t]{2}{*}{ Drug } & \multirow[t]{2}{*}{ Parameters } & \multicolumn{3}{|l|}{ Host } & \multirow{2}{*}{$\begin{array}{l}\text { Overall } \\
\text { livestock }^{2}\end{array}$} \\
\hline & & Cattle & Goat & Sheep & \\
\hline \multirow[t]{6}{*}{$\overline{B Z^{b}}$} & N studies (\%) & $7(17.5)$ & $15(37.5)$ & $23(57.5)$ & 40 \\
\hline & $\mathrm{N}$ hosts & 3417 & 1697 & 11,342 & 16,531 \\
\hline & FECRT (\%) & & & & \\
\hline & Minimum & 7.3 & 20.8 & 0 & 0 \\
\hline & Maximum & 95.9 & 90.0 & 90.0 & 100 \\
\hline & Mean & 75.3 & 64.8 & 47.0 & 55.0 \\
\hline \multirow[t]{6}{*}{ ALB } & N studies (\%) & 7 (22.6) & $11(35.5)$ & $16(51.6)$ & 31 \\
\hline & $N$ hosts & 3417 & 604 & 8878 & 12,915 \\
\hline & FECRT (\%) & & & & \\
\hline & Minimum & 7.3 & 29.5 & 0 & 0 \\
\hline & Maximum & 95.7 & 90.0 & 90.0 & 100 \\
\hline & Mean & 75.4 & 68.1 & 55.1 & 58.6 \\
\hline \multirow[t]{6}{*}{ OXF } & N studies (\%) & 0 & $4(36.4)$ & $7(63.6)$ & 11 \\
\hline & $N$ hosts & & 1118 & 2464 & 3614 \\
\hline & FECRT (\%) & & & & \\
\hline & Minimum & & 20.8 & 0 & 0 \\
\hline & Maximum & & 73.5 & 64.9 & 92.4 \\
\hline & Mean & & 56.6 & 29.7 & 46.9 \\
\hline
\end{tabular}

aincluding cattle, goat, sheep, and others (equine and ostrich). ${ }^{\mathrm{b}}$ including ALB, FEN, MEB, OXF, RIC, and THI the FLOTAC technique, was used in only one study. Coproculture was performed in $33 / 40$ (82.5\%) of the studies to identify the nematode genus through morphological analyses of the larvae. Through coproculture, the following parasite genera were identified (Table 1): Haemonchus (32.2\%), Trichostrongylus (21.7\%), Oesophagostomum (16.1\%), Cooperia (9.6\%), Strongyloides (8.8\%), Ostertagia (5.6\%), and others (Strongylus, Bunostomum, Teladorsagia, Trichuris, Libyostrongylus, 5.6\%). Sheep exhibited a greater diversity of parasites compared to other animal hosts (Fig. 2a), with the following genera identified: Cooperia, Haemonchus, Oesophagostomum, Ostertagia, Strongyloides, and Trichostrongylus. In Fig. 2b, it noted the number of studies that identified the parasite species and the studied drug. However, it was not possible to establish a relationship between a specific parasite genera and BZ effectiveness. Four studies (9.3\%) used molecular techniques to evaluate potential BZ resistance. The characteristic mutation at codon F200Y of the beta-tubulin gene was the most frequently observed mutation (100\%) in Haemonchus parasites, yet the F167Y mutation in the same gene was found in only two studies (50\%).

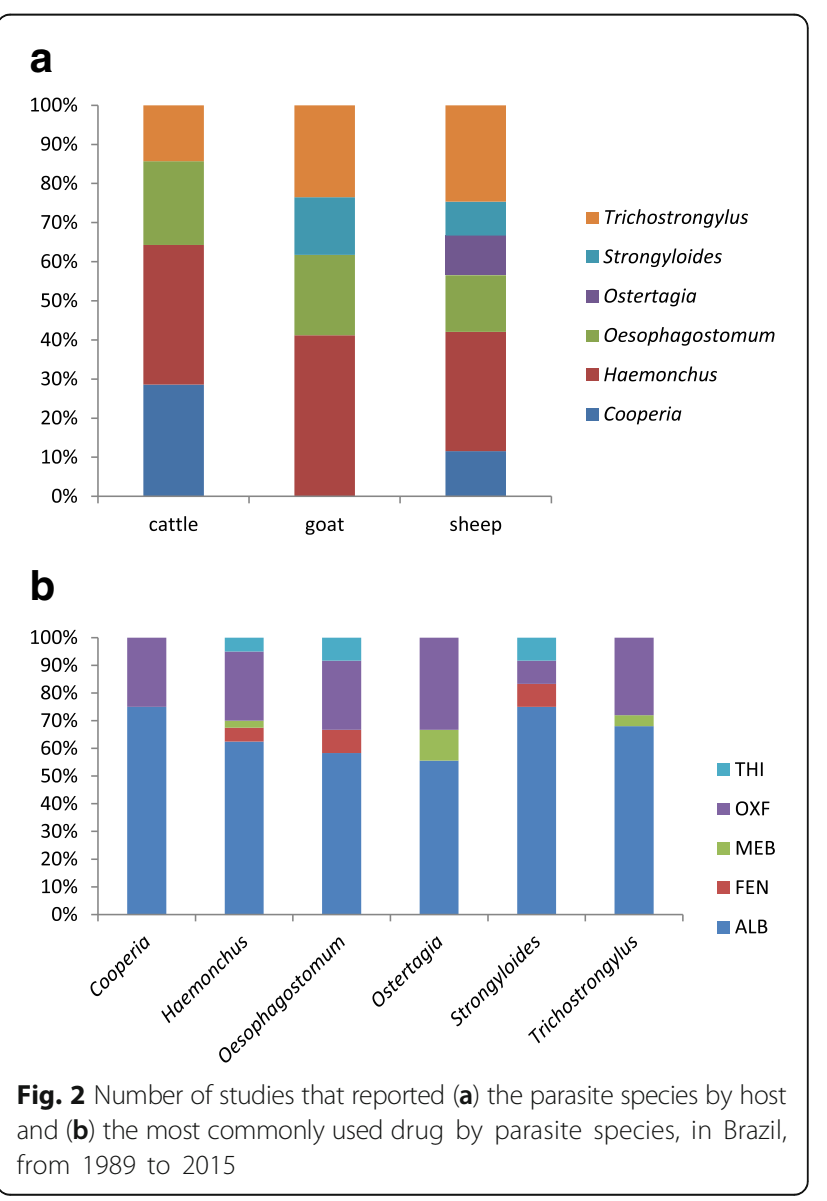


It was observed through linear regression that FECRT is significantly reduced over time between 2007 and 2014 $(R=-0.653 p=0.021)$ for the treatment of cattle with BZ, suggesting progressive loss of effectiveness and increased resistance for these hosts (Fig. 3).

\section{Discussion}

This study presents a systematic review on a subject still under-explored in Brazil: BZ resistance in nematode parasites.

We observed that BZ resistance was widely disseminated in animal hosts in Brazil and demonstrated that $\mathrm{BZ}$ had lower effectiveness in sheep. BZ resistance in livestock has been widely distributed throughout the world since the development of the drugs in the early 1960s [7]. The extensive use of BZ led to an immense selection pressure on parasite populations, particularly in the gastrointestinal parasites of ruminants, most notably sheep [7]. Grazing animals defecate where they feed, and even after treatment, reinfection is common, leading to an overuse of BZs. In this context, anthelmintic drugs are often used as a single tool for nematode control, extensively and indiscriminately. Many farms provide various annual doses of BZ drugs to animals, allowing for a considerable selective pressure on parasitic nematodes, and the spread of resistance.

Many livestock studies report an inefficient management system, as well as, a lack of knowledge about the correct use and dosage of drugs and not respecting the interval time between dosage administrations [15-18]. This has a great impact on treatment efficacy. In Brazil, the SICOPA (Sistema Integrado de Controle Parasitário) [19] consists of a set of strategies for the treatment of the flock to preserve the drug susceptibility characteristics and considers the epidemiological characteristics of the country [20]. However, the monitoring of drug efficacy is rarely used or even non-existent on some farms in Brazil [19]. Therefore, some measures must be implemented in farms in order to reduce the selective pressure and the spread of resistance to anthelmintics: i) establish the parasitological diagnosis; ii) determine the FECRT routinely, as well as the susceptibility of the host population (naïve, preparturition, post parturition); iii) weigh the animals to avoid underdosage; iv) anthelmintic drug rotation (annually); and v) anthelmintic treatments not administered at intervals shorter than 28 days [19-23].

Brazil is a major producer of animals and meat for exportation to the world market, approximately 230 million animals are produced annually [4]. Nonetheless, only 13 of the 27 Brazilian states were analysed for BZ resistance. Cattle production is well distributed in the country, especially in the states of the Midwest (33.6\% of total production in the country) - specifically the states of Mato Grosso (13.4\%) and Goiás (10.2\%) - and the North Region is the second largest producer of cattle

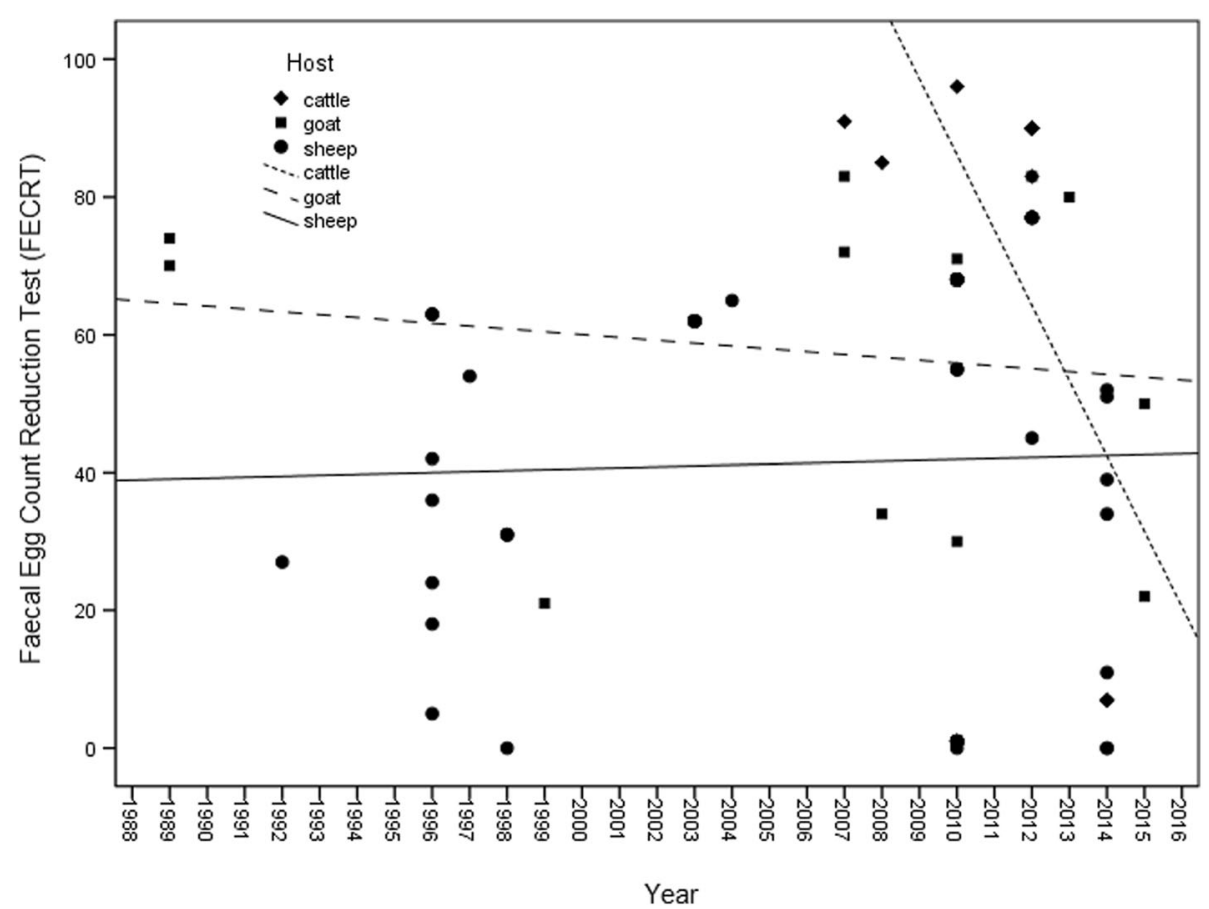

Fig. 3 Simple linear regression analysis (lines) of Faecal Egg Count Reduction Test (FECRT) by time (years) reported in livestock in Brazil, from 1989 to 2015, stratified by host. Cattle $R=-0.653 p=0.021$; goat $R=-0.154 p=0.633$; and sheep $R=0.029 p=0.820$ ) 
(21.2\%) [4]. However, no work has been published reporting the effectiveness of BZ in these regions. Only one study was conducted in Mato Grosso do Sul (Midwest Region) and analysed sheep nematodes. The states of the Northeast and South Regions are the largest producers of sheep $(56.5 \%$ and $30 \%$ of total production of the country, respectively), and the states of the Northeast are the main producers of goats, with $91.4 \%$ of the total production [4]. In these regions there was research available on BZ resistance of STHs in herds, both in sheep and goats. Nevertheless, the data shows us that there is a gap in knowledge - both in diagnosis and research - about the reality of resistance in livestock in the country.

The origin of BZ resistance in livestock has been speculated about. The animal migration and gene flow among nematodes [24], as well as spontaneous mutations [25] and the presence of rare alleles in the population [26], could be responsible for the spread of resistance among animal nematodes. Currently, there is concern about the possibility of the emergence of resistance to the drugs used in soil transmitted helminthes (STH) control; however, the large-scale mass drug administration strategy is generally the cornerstone of most STH control programmes $[27,28]$. Until now, the degree of influence that resistance in livestock can have on the development and spread of resistance in human nematodes is unknown, particularly in nematodes with zoonotic potential, such as Ascaris suum and Trichostrongylus.

The egg count using the McMaster chamber, and several variations on the original technique, is the most frequently used technique to conduct the FECRT. The FECRT is an in vitro test that provides an estimate of anthelmintic efficacy by comparing worm egg counts from animals before and after treatment [13]. The McMaster technique is widely used in veterinary parasitology and has been recommended by the WHO for evaluation of the EPG count in humans [29]. The FLOTAC technique was used in only one study [30]. FLOTAC and Mini-FLOTAC techniques [31, 32] present potential for the qualitative and quantitative copromicroscopic diagnosis of parasites in a practical and simple way, and should be considered.

In $17.5 \%$ of the studies (7/40), the faecal culture technique was not carried out to identify the nematode genus that had infected the animals. This is a matter of great importance in assessing the BZ resistance in animal nematodes, because the diagnosis based on egg observation does not indicate the parasite genus involved, and in mixed infections, only one species may be resistant to the BZ drug [33]. In addition, only one study conducted an in vitro test - the egg hatch test - to detect the nematode species involved in BZ resistance. The egg hatch test can be used for detection of $\mathrm{BZ}$ resistance by assessing the drug's ability to inhibit embryonation of the parasite [13, 34].

The molecular signature of $\mathrm{BZ}$ resistance in nematodes is the presence of SNPs in the $\beta$-tubulin isotype 1 gene in nematodes, located at codons F167Y (TTC/ Phe $\rightarrow$ TAC/Tyr), E198A (GAG/Glu $\rightarrow$ GCG/Ala) and F200Y (TTC/Phe $\rightarrow$ TAC/Tyr) $[6,35,36]$. Despite the fact that these genetic markers of $\mathrm{BZ}$ resistance are known, few studies $(4 / 43,9.3 \%)$ used molecular techniques for the evaluation of resistance of nematodes in Brazil. Of these studies, all Haemonchus nematodes demonstrated the mutation F200Y. Additionally, the codon F167Y was found in Haemonchus parasites in two studies. These findings in Brazil are in agreement with previous studies, which demonstrated that the F200Y mutation is the most frequently found mutation associated with $\mathrm{BZ}$ resistance in nematodes, and has been described in various nematode parasites: Haemonchus [36], Ostertagia [37], Cooperia [38], Ancylostoma caninum [39], human hookworms and T. trichiura [10, 40]. Moreover, Haemonchus contortus has been determined to be responsible for the rapid development of $\mathrm{BZ}$ resistance in nematodes of small ruminants, probably due to its high genetic diversity and consequent greater availability for new mutations [41, 42].

\section{Conclusions}

The scenario of BZ resistance in nematode populations of domestic animals in Brazil is not favourable. Given the high cost of drug discovery and development, it is urgent to implement control measures and to monitor the effectiveness/resistance to nematodes in livestock in Brazil. Considering the BZ-R scenario observed in this study, a greater investment in animal management and adequate control of the use of anthelmintic drugs should be performed in the country.

\section{Abbreviations \\ AL: Alagoas; ALB: albendazole; BA: Bahia; BZ: benzimidazole; CE: Ceará; epg: Eggs per gram of faeces; FECRT: Faecal Egg Count Reduction Test; FEN: fenbendazole; MEB: mebendazol; MG: Minas Gerais; MS: Mato Grosso do Sul; OXF: oxfendazole; PB: Paraíba; PE: Pernambuco; PR: Paraná; RIC: ricobendazole; RJ: Rio de Janeiro; RN: Rio Grande do Norte; RS: Rio Grande do Sul; SC: Santa Catarina; SNPs: Single nucleotide polymorphisms; SP: São Paulo; THI: Thiabendazole}

Acknowledgements

We thank American Journal Experts (AJE) for English language editing.

Funding

FACC has a productivity research grant of CNPq, Brazil.

\section{Availability of data and materials}

The dataset supporting the conclusions of this article is included within the article (and its additional files).

Authors' contributions

$\mathrm{LHJ}$ and FACC conceived and designed the study. LHJ conducted the systematic literature search and data extraction. LHJ and FACC analyzed and interpreted the 
data, and wrote the manuscript. Both authors have read and approved the final version of this manuscript.

\section{Ethics approval and consent to participate.}

Not applicable.

\section{Consent for publication}

Not applicable.

\section{Competing interests}

The authors declare that they have no competing interests.

\section{Publisher's Note}

Springer Nature remains neutral with regard to jurisdictional claims in published maps and institutional affiliations.

\section{Author details}

'Laboratório de Epidemiologia e Sistemática Molecular, Instituto Oswaldo Cruz, Fundação Oswaldo Cruz, Pavilhão Leônidas Deane, sala 308, Avenida Brasil 4365, Manguinhos, Rio de Janeiro, RJ 21040-900, Brazil. ${ }^{2}$ Fundação Oswaldo Cruz, Rua Magalhães Filho, 519, Teresina, Piauí 64000-128, Brazil.

\section{Received: 9 May 2017 Accepted: 17 November 2017}

Published online: 25 November 2017

\section{References}

1. Rist CL, Garchitorena A, Ngonghala CN, Gillespie TR, Bonds MH. The burden of livestock parasites on the poor. Trends Parasitol. 2015:31:527-30.

2. Fortes FS, Molento MB. Resistência anti-helmíntica em nematoides gastrintestinais de pequenos ruminantes: avanços e limitações para seu diagnóstico. Pesq Vet Bras. 2013;33:1391-402.

3. Vieira LS. Endoparasitoses gastrintestinais em caprinos e ovinos. Empresa Brasileira de Pesquisa Agropecuária: Sobral; 2005.

4. IBGE. Produção da Pecuária Municipal 2013. Rio de Janeiro: Instituto Brasileiro de Geografia e Estatística; 2014.

5. Lacey E. Mode of action of Benzimidazoles. Parasitol Today. 1990;6:112-5.

6. Silvestre A, Cabaret J. Mutation in position 167 of isotype 1 beta-tubulin gene of Trichostrongylid nematodes: role in benzimidazole resistance? Mol Biochem Parasitol. 2002:120:297-300.

7. Lacey E, Gill JH. Biochemistry of benzimidazole resistance. Acta Trop. 1994; 56:245-62.

8. Bennett A, Guyatt H. Reducing intestinal nematode infection: efficacy of albendazole and mebendazole. Parasitol Today. 2000;16:71-4.

9. Prichard RK. Mechanisms of anthelmintic resistance: implications for the future of parasite control. Proc. 15th Congr. Bras.Parasit. Vet. Brazil. 2008;21:62-8.

10. Diawara A, Halpenny CM, Churcher TS, Mwandawiro C, Kihara J, Kaplan RM, et al. Association between response to albendazole treatment and $\beta$-tubulin genotype frequencies in soil-transmitted helminths. PLoS Negl Trop Dis. 2013;7:e2247.

11. Vercruysse J, Albonico M, Behnke JM, Kotze AC, Prichard RK, McCarthy JS, et al. Is anthelmintic resistance a concern for the control of human soil-transmitted helminths? Int J Parasitol Drugs Drug Resist. 2011;1:14-27.

12. Moher D, Liberati A, Tetzlaff J, Altman DG, PRISMA group. Preferred reporting items for systematic reviews and meta-analyses: the PRISMA statement. Int J Surg. 2010;8:336-41.

13. Coles GC, Bauer C, Borgsteede FH, Geerts S, Klei TR, Taylor MA, et al. World Association for the Advancement of veterinary parasitology (W.A.A.V.P.) methods for the detection of anthelmintic resistance in nematodes of veterinary importance. Vet Parasitol. 1992:44:35-44.

14. GMC/Mercosul. Resolução 76/1996 - Regulamento Técnico para Registro de Produtos Antiparasitários de Uso Veterinário. Brasília: Grupo Mercado Comum: 1996.

15. Borges SL, Oliveira AA, Mendonça LR, Lambert SM, Viana JM, Nishi SM, et al. Resistência anti-helmíntica em rebanhos caprinos nos biomas Caatinga e Mata Atlântica. Pesq Vet Bras. 2015;35:643-8.

16. Cezar AS, Toscan G, Camillo G, Sangioni LA, Ribas HO, Vogel FS. Multiple resistance of gastrointestinal nematodes to nine different drugs in a sheep flock in southern Brazil. Vet Parasitol. 2010;173:157-60.

17. Coelho WAC, Ahid SMM, Vieira LS, Fonseca ZAAS, Silva IP. Resistência antihelmíntica em caprinos no município de Mossoró. RN Ci Anim Bras. 2010; 11:589-99.
18. da Cruz DG, da Rocha LO, Arruda SS, Palieraqui JG, Cordeiro RC, Santos E Jr, et al. Anthelmintic efficacy and management practices in sheep farms from the state of Rio de Janeiro, Brazil. Vet Parasitol. 2010;170:340-3.

19. Molento MB. Resistência de helmintos em ovinos e caprinos. Rev Bras Parasitol Vet. 2004;13(Suppl 1):82-7.

20. Hammerschmidt J, Bier D, Fortes FS, Warzensaky P, Bainy AM, Macedo AAS, et al. Avaliação do sistema integrado de controle parasitário em uma criação semiintensiva de caprinos na região de Santa Catarina. Arq Bras Med. Vet Zootec. 2012:64:927-34.

21. Thomas-Soccol VT, Sotomaior C, Souza FP, Castro EA, Pessôa Silva MC Milczewski $V$. Occurrence of resistance to anthelmintics in sheep in Paraná state, Brazil. Vet Rec. 1996;139:421-2.

22. Thomaz-Soccol V, Souza FP, Sotomaior C, Castro EA, Milczewski V, Mocelin G, et al. Resistance of gastrointestinal nematodes to Anthelmintics in sheep (Ovis aries). Braz Arch Biold Technol. 2004:47:41-7.

23. Leathwick DM, Ganesh S, Waghorn TS. Evidence for reversion towards anthelmintic susceptibility in Teladorsagia circumcincta in response to resistance management programmes. Int J Parasitol Drugs Drug Resist. 2015:5:9-15.

24. Silvestre A, Humbert JF. Diversity of benzimidazole-resistance alleles in populations of small ruminant parasites. Int J Parasitol. 2002;32:921-8.

25. Humbert JF, Cabaret J, Elard L, Leignel V, Silvestre A. Molecular approaches to studying benzimidazole resistance in trichostrongylid nematode parasites of small ruminants. Vet Parasitol. 2001;101:405-14.

26. Roos MH, Boersema JH, Borgsteede FH, Cornelissen J, Taylor M, Ruitenberg EJ. Molecular analysis of selection for benzimidazole resistance in the sheep parasite Haemonchus contortus. Mol Biochem Parasitol. 1990;43:77-88.

27. Rashwan N, Bourguinat C, Keller K, Gunawardena NK, de Silva N, Prichard R. Isothermal diagnostic assays for monitoring single nucleotide polymorphisms in Necator Americanus associated with Benzimidazole drug resistance. PLoS Negl Trop Dis. 2016;10:e0005113.

28. Krücken J, Fraundorfer K, Mugisha JC, Ramünke S, Sifft KC, Geus D, et al. Reduced efficacy of albendazole against Ascaris lumbricoides in Rwandan schoolchildren. Int J Parasitol Drugs Drug Resist. 2017:7(3):262-71.

29. WHO. Assessing the epidemiology of soil-transmitted helminths during a transmission assessment survey in the global programme for the elimination of lymphatic filariasis. Geneva: World Health Organization; 2015.

30. das Neves JH, Carvalho N, Rinaldi L, Cringoli G, Amarante AF. Diagnosis of anthelmintic resistance in cattle in Brazil: a comparison of different methodologies. Vet Parasitol. 2014;206:216-26.

31. Cringoli G, Rinaldi L, Maurelli MP, Utzinger JFLOTAC. New multivalent techniques for qualitative and quantitative copromicroscopic diagnosis of parasites in animals and humans. Nat Protoc. 2010;5:503-15.

32. Barda BD, Rinaldi L, lanniello D, Zepherine H, Salvo F, Sadutshang T, et al. Mini-FLOTAC, an innovative direct diagnostic technique for intestinal parasitic infections: experience from the field. PLoS Negl Trop Dis. 2013;7(8):e2344.

33. Prichard RK, Hall CA, Kelly JD, Martin IC, Donald AD. The problem of anthelmintic resistance in nematodes. Aust Vet J. 1980;56:239-51.

34. Coles GC, Jackson F, Pomroy WE, Prichard RK, von Samson-Himmelstjerna G, Silvestre $A$, et al. The detection of anthelmintic resistance in nematodes of veterinary importance. Vet Parasitol. 2006;136:167-85.

35. Kwa MS, Veenstra JG, Roos MH. Benzimidazole resistance in Haemonchus contortus is correlated with a conserved mutation at amino acid 200 in beta-tubulin isotype 1. Mol Biochem Parasitol. 1994;63:299-303.

36. Ghisi M, Kaminsky R, Mäser P. Phenotyping and genotyping of Haemonchus contortus isolates reveals a new putative candidate mutation for benzimidazole resistance in nematodes. Vet Parasitol. 2007:144:313-20.

37. Knapp-Lawitzke F, Krücken J, Ramünke S, von Samson-Himmelstjerna G, Demeler J. Rapid selection for $\beta$-tubulin alleles in codon 200 conferring benzimidazole resistance in an Ostertagia ostertagi isolate on pasture. Vet Parasitol. 2015;209:84-92

38. Demeler J, Krüger N, Krücken J, von der Heyden VC, Ramünke S, Küttler U, et al. Phylogenetic characterization of $\beta$-tubulins and development of pyrosequencing assays for benzimidazole resistance in cattle nematodes. PLoS One. 2013;8:e70212

39. Furtado LF, Bello AC, Dos Santos HA, Carvalho MR, Rabelo ÉM. First identification of the F200Y SNP in the $\beta$-tubulin gene linked to benzimidazole resistance in Ancylostoma caninum. Vet Parasitol. 2014;206:313-6.

40. Diawara A, Drake LJ, Suswillo RR, Kihara J, Bundy DA, Scott ME, et al. Assays to detect beta-tubulin codon 200 polymorphism in Trichuris trichiura and Ascaris lumbricoides. PLoS Negl Trop Dis. 2009;3:e397. 
41. Melo AC, Bevilaquia CM. Genetic approach of anthelmintic resistance in Haemonchus contortus. RPCV. 2005;100:141-6.

42. Redman E, Whitelaw F, Tait A, Burgess C, Bartley Y, Skuce PJ, et al. The emergence of resistance to the benzimidazole anthlemintics in parasitic nematodes of livestock is characterised by multiple independent hard and soft selective sweeps. PLoS Negl Trop Dis. 2015;9:e0003494.

43. Ahid SMM, Cavalcante MDA, Bezerra ACDS, Soares HS, Pereira RHMA Eficácia anti-helmíntica em rebanho caprino no estado de Alagoas. Brasil Acta Veter Brasilica. 2007;1:56-9.

44. Amarante AFT, Barbosa MA, Oliveira MAG, Carmelo MJ, Padovani CR. Efeito da administração de oxfendazol, ivermectina e levamisol sobre os exames coproparasitológicos de ovinos. Braz J Vet. 1992;29:31-8.

45. Araujo NKS, Ahid SMM, Bezerra ACDS, Dias RGC, Ferreira HIP, Fagundes Neto JC, et al. Avaliação da eficácia dos anti-helmínticos ricobendazole e abamectina gel composto em equinos de Vaquejada. Acta Veter Brasilica. 2008;2:47-9.

46. Borges FA, Nakamura AY, Almeida GD, Cadamuro VHA. Eficácia de formulações anti-hemílticas comerciais em equinos no município de Douradina. Paraná Ci Anim Bras. 2010;11:618-22.

47. Brasil BS, Nunes RL, Bastianetto E, Drummond MG, Carvalho DC, Leite RC, et al. Genetic diversity patterns of Haemonchus placei and Haemonchus contortus populations isolated from domestic ruminants in Brazil. Int J Parasitol. 2012;42: 469-79.

48. Bruhn FRP, Lopes MA, Perazza CA, Demeu FA, Santos G, Franco Neto A, et al. Eficiência técnica e econômica da aplicação de diferentes anti-helmínticos em fêmeas da raça holandesa na fase de recria durante o outono-inverno de 2009. Acta Tecnológica. 2012;7:25-30.

49. Cunha Filho LFC, Pereira ABL, Yamamura MH. Resistência a anti-helmínticos em ovinos da Região de Londrina, Paraná. Brasil Semina Ci Agr. 1998;19:31-7.

50. de Souza LP, Lelis RT, Granja IR, DaMatta RA, Santos Cde P. Efficacy of albendazole and moxidectin and resistance to ivermectin against Libyostrongylus douglassii and Libyostrongylus dentatus in ostriches. Vet Parasitol. 2012;189:387-9.

51. dos Santos JM, Monteiro JP, Ribeiro WL, Macedo IT, Camurça-Vasconcelos AL, Vieira Lda S, et al. Identification and quantification of benzimidazole resistance polymorphisms in Haemonchus contortus isolated in northeastern Brazil. Vet Parasitol. 2014;199:160-4.

52. Duarte ER, Silva RB, Vasconcelos VO, Nogueira FA, Oliveira NJF. Diagnóstico do controle e perfil de sensibilidade de nematódeos de ovinos ao albendazol e ao levamisol no norte de Minas Gerais. Pesq Vet Bras. 2012;32:147-52.

53. Echevarria F, Borba MF, Pinheiro AC, Waller PJ, Hansen JW. The prevalence of anthelmintic resistance in nematode parasites of sheep in southern Latin America: Brazil. Vet Parasitol. 1996;62:199-206.

54. Farias MT, Bordin EL, Forbes $A B$, Newcomb KA. Survey on resistance to anthelmintics in sheep stud farms of southern Brazil. Vet Parasitol. 1997; 72:209-14.

55. Klauck V, Pazinato R, Lopes LS, Cucco DC, Lima HL, Volpato A, et al. Trichostrongylus and Haemonchus anthelmintic resistance in naturally infected sheep from southern Brazil. An Acad Bras Cienc. 2014;86:777-84.

56. Lima MM, Farias MPO, Romeiro ET, Ferreira DRA, Alves LC, Faustino MAG. Eficácia da moxidectina, ivermectina e albendazole contra helmintos gastrintestinais em propriedades de criação caprina e ovina no estado de Pernambuco. Ci Anim Bras. 2010;11:94-100.

57. Lima WC, Athayde ACR, Medeiros GR, Lima DASD, Borburema JB, Santos EM, et al. Nematoides resistentes a alguns anti-helmínticos em rebanhos caprinos no Cariri Paraibano. Pesq Vet Bras. 2010;30:1003-9.

58. Melo CFL, Bevilaquia CML, Selaive AV, Girão MD. Resistência a anti-helmínticos em nematoides gastrintestinais de ovinos e caprinos, no município de Pentecoste, estado do Ceará. Ciência. Animal. 1998:8:7-11.

59. Melo ACFL, Reis IF, Bevilaquia CML, Vieira LS, Echevarria FAM, Melo LM. Nematódeos resistentes a anti-helmíntico em rebanhos de ovinos e caprinos do estado do Ceará, Brasil. Ciência Rural. 2003;33:339-44.

60. Niciura SC, Veríssimo CJ, Gromboni JG, Rocha MI, de Mello SS, Barbosa CM, et al. F200Y polymorphism in the $\beta$-tubulin gene in field isolates of Haemonchus contortus and risk factors of sheep flock management practices related to anthelmintic resistance. Vet Parasitol. 2012;190:608-12.

61. Nunes RL, Santos LL, Bastianetto E, Oliveira DAA, Brasil BSAF. Frequency of benzimidazole resistance in Haemonchus contortus populations isolated from buffalo, goat and sheep herds. Rev Bras Parasitol Vet. 2013;22:548-53.

62. Pereira RHMA, Ahid SMM, Bezerra ACDS, Soares HS, Fonseca ZAAS. Diagnóstico da resistência dos nematoides gastrintestinais a anti-helmínticos em rebanhos caprino e ovino do RN. Acta Veter Brasilica. 2008;2:16-9.
63. Ramos Cl, Bellato V, Ávila VS, Coutinho GC, Souza AP. Resistência de parasitos gastrintestinais de ovinos a alguns anti-helmínticos no estado de Santa Catarina, Brasil. Ciência Rural. 2002;32:473-7.

64. Rodrigues AB, Athayde ACR, Rodrigues OG, Silva WW, Faria EB. Sensibilidade dos nematóides gastrintestinais de caprinos a anti-helmínticos na mesorregião do Sertão Paraibano. Pesq Vet Bras. 2007;27:162-6.

65. Santos FCC, Buzatti A, Scheuermann MM, Roll VFB, Vogel FSF. Resistência múltipla á anti-helmínticos num rebanho ovino no sul do Brasil. RPCV. 2014; 109:33-7.

66. Sczesny-Moraes EA, Bianchin I, Silva F, Catto JB, Honer MR, Paiva F. Resistência anti-helmíntica de nematoides gastrintestinais em ovinos, Mato Grosso do Sul. Pesq Vet Bras. 2010;30:229-36.

67. Soutello RG, Seno MC, Amarante AF. Anthelmintic resistance in cattle nematodes in northwestern São Paulo state, Brazil. Vet Parasitol. 2007; 148:360-4.

68. Soutello RVG, Coelho WMD, Oliveira FP, Fonzar JF, Luquetti BC, Souza RFP, et al. Evaluation of reduction in egg shedding of gastrointestinal nematodes in cattle following administration of anthelmintics. Rev Bras Parasitol Vet. 2010;19: $183-5$.

69. Souza AP, Ramos Cl, Bellatol V, Sartor AA, Schelbauer CA. Resistência de helmintos gastrintestinais de bovinos a anti-helmínticos no Planalto Catarinense. Ciência Rural. 2008:38:1363-7.

70. Souza ALSO, Athayde ACR, Olinto FA. Sensibilidade dos nematoides gastrintestinais de caprinos leiteiros à anti-helmínticos no município de Sumé, Paraíba. Brasil ACSA. 2013;9:33-6.

71. Veríssimo CJ, Niciura SC, Alberti AL, Rodrigues CF, Barbosa CM, Chiebao DP, et al. Multidrug and multispecies resistance in sheep flocks from São Paulo state, Brazil. Vet Parasitol. 2012;187:209-16.

72. Vieira LS, Cavalcante ACR. Resistência anti-helmíntica em rebanhos caprinos no Estado do Ceará. Pesq Vet Bras. 1999;19:99-103.

73. Vieira LS, Gonçalves PC, Costa CAF, Berne MEA. Redução e esterilização de ovos de nematódeos gastrintestinais em caprinos medicados com antihelmínticos benzimidazóis. Pesq Agropec Bras. 1989;24:1255-65.

74. Vieira LS, Berne MEA, Cavalcante ACR, Menezes RCAA. Redução do número de ovos por grama de fezes (opg) em caprinos e ovinos medicados com anti-helmíntico. Bol Pes Embrapa. 1989;11:5-14.

\section{Submit your next manuscript to BioMed Central and we will help you at every step:}

- We accept pre-submission inquiries

- Our selector tool helps you to find the most relevant journal

- We provide round the clock customer support

- Convenient online submission

- Thorough peer review

- Inclusion in PubMed and all major indexing services

- Maximum visibility for your research

Submit your manuscript at www.biomedcentral.com/submit
C) Biomed Central 